\title{
Elevated high-sensitivity troponin T levels at 1-year follow-up are associated with increased long-term mortality after TAVR
}

\author{
Hatim Seoudy ${ }^{1,2} \cdot$ Moritz Lambers $^{3} \cdot$ Vincent Winkler $^{1} \cdot$ Linnea Dudlik $^{1} \cdot$ Sandra Freitag-Wolf $^{4} \cdot$ Johanne Frank $^{1,2}$. \\ Christian Kuhn ${ }^{1,2}$. Ashraf Yusuf Rangrez ${ }^{1,2} \cdot$ Thomas Puehler $^{2,5} \cdot$ Georg Lutter $^{2,5} \cdot$ Peter Bramlage $^{6} \mathbb{\mathbb { D }}$. \\ Norbert Frey ${ }^{1,2} \cdot$ Derk Frank $^{1,2}$
}

Received: 20 August 2020 / Accepted: 5 October 2020 / Published online: 24 October 2020

(c) The Author(s) 2020

\begin{abstract}
Background Elevated pre-procedural high-sensitivity troponin $\mathrm{T}$ (hs-TnT) levels predict adverse outcomes in patients with severe aortic stenosis (AS) undergoing transcatheter aortic valve replacement (TAVR). It is unknown whether elevated troponin levels still provide prognostic information during follow-up after successful TAVR. We evaluated the long-term implications of elevated hs-TnT levels found at 1-year post-TAVR.

Methods and results The study included 349 patients who underwent TAVR for severe AS from 2010-2019 and for whom 1-year hs-TnT levels were available. Any required percutaneous coronary interventions were performed $>1$ week before TAVR. The primary endpoint was survival time starting at 1-year post-TAVR. Optimal hs-TnT cutoff for stratifying risk, identified by ROC analysis, was $39.4 \mathrm{pg} / \mathrm{mL} .292$ patients had hs-TnT $<39.4 \mathrm{pg} / \mathrm{mL}$ (median $18.3 \mathrm{pg} / \mathrm{mL}$ ) and $57 \mathrm{had} \mathrm{hs}-\mathrm{TnT} \geq 39.4 \mathrm{pg} / \mathrm{mL}$ (median $51.2 \mathrm{pg} / \mathrm{mL}$ ). The high hs-TnT group had a higher median N-terminal pro-B-type natriuretic peptide (NT-proBNP) level, greater left ventricular (LV) mass, higher prevalence of severe diastolic dysfunction, LV ejection fraction $<35 \%$, severe renal dysfunction, and more men compared with the low hs-TnT group. All-cause mortality during follow-up after TAVR was significantly higher among patients who had hs-TnT $\geq 39.4 \mathrm{pg} / \mathrm{mL}$ compared with those who did not (mortality rate at 2 years post-TAVR: $12.3 \%$ vs. $4.1 \%, p=0.010$ ). Multivariate analysis identified 1 -year hs-TnT $\geq 39.4 \mathrm{pg} / \mathrm{mL}$
\end{abstract}

Hatim Seoudy and Moritz Lambers contributed equally.

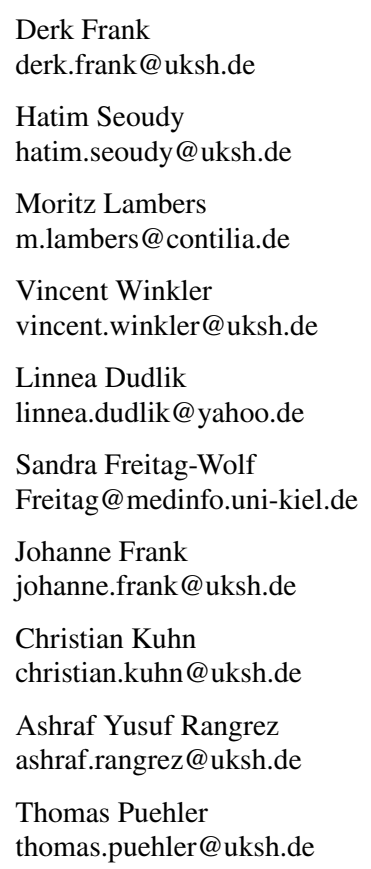

Georg Lutter

georg.lutter@uksh.de

Peter Bramlage

peter.bramlage@ippmed.de

Norbert Frey

norbert.frey@uksh.de

1 Department of Internal Medicine III, Cardiology and Angiology, University Hospital Schleswig-Holstein Kiel, Arnold-Heller-Str.3, Haus K3, 24105 Kiel, Germany

2 DZHK (German Centre for Cardiovascular Research), Partner Site Hamburg/ Kiel/ Lübeck, Kiel, Germany

3 Department of Cardiology and Angiology, Contilia Heart and Vascular Centre Elisabeth-Krankenhaus, Essen, Germany

4 Department of Medical Informatics and Statistics, University Hospital Schleswig-Holstein, Campus Kiel, Kiel, Germany

5 Department of Cardiovascular Surgery, University Hospital Schleswig-Holstein, Kiel, Germany

6 Institute for Pharmacology and Preventive Medicine, Cloppenburg, Germany 
(hazard ratio 2.93, 95\% CI 1.91-4.49, $p<0.001$ ), NT-proBNP level $>300 \mathrm{pg} / \mathrm{mL}$, male sex, an eGFR $<60 \mathrm{~mL} / \mathrm{min} / 1.73 \mathrm{~m}^{2}$ and chronic obstructive pulmonary disease as independent risk factors for long-term mortality after TAVR.

Conclusions Elevated hs-TnT concentrations at 1-year after TAVR were associated with a higher long-term mortality.

\section{Graphic abstract}

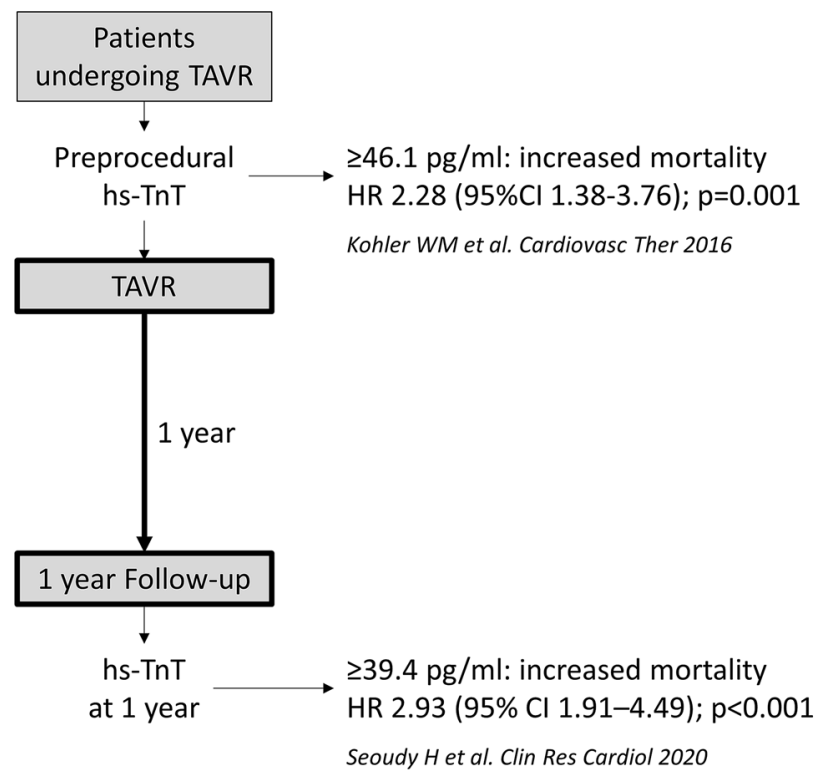

Keywords Troponin $\mathrm{T} \cdot$ Transcatheter aortic valve replacement $\cdot$ Aortic stenosis $\cdot$ Survival

\section{Introduction}

Aortic stenosis (AS) is one of the most common heart valve diseases in the Western world with an estimated prevalence of $3-23 \%$, depending on age [1]. Transcatheter aortic valve replacement (TAVR), which was introduced as an alternative for patients deemed unsuitable for conventional open heart surgery, is now considered the treatment of choice in high-risk patients with severe symptomatic AS, and has also become a viable alternative to surgery in low-to-intermediate-risk patients $[2,3]$.

In recent years, various biomarkers and multimarker approaches have been studied in the context of AS [4]. High-sensitivity troponin T (hs-TnT) is frequently elevated in patients with severe AS, and we and others have demonstrated that pre-procedural high-sensitive hs-TnT predicts survival after TAVR, with elevated pre-procedural hs-TnT representing an independent predictor of all-cause mortality after TAVR [5-8]. However, the potential role of hs-TnT in risk stratification during follow-up of patients after TAVR remains undefined. Wall stress and subsequent left ventricular (LV) hypertrophy are thought to be major drivers of pre-procedural increased hs-TnT in patients with AS [9], and treatment of severe AS with TAVR leads to an immediate drop in afterload and wall stress in the left ventricle.
Thus, elevated hs-TnT values would be expected to decrease shortly after TAVR and definitely by 1 -year after treatment.

The objective of our study was to evaluate the prognostic implication of elevated hs-TnT levels found at 1-year after successful TAVR. The hypothesis was that hs-TnT level at 1-year post successful TAVR would still be associated with future survival.

\section{Methods}

\section{Study design}

A total of 953 patients undergoing transfemoral TAVR at our institution for symptomatic severe AS between March 2010 and October 2019 were identified from our TAVR database. Follow-up data including 1-year hs-TnT levels were available for 349 patients who were, therefore, selected for our study. At the follow-up visits, patients were assessed by an experienced cardiologist. Based on the patient's history, clinical exam and ECG there was no sign of acute myocardial infarction in any of the patients. Patients with an acute myocardial infarction were thus not part of our study.

The primary endpoint of the study was survival time beginning at 1 year after TAVR. The data collection was 
conducted in accordance with the Declaration of Helsinki and was approved by the local ethics committee at the University of Kiel. All patients provided written informed consent prior to the procedure and data acquisition.

\section{Data collection}

Pre-procedural blood samples and patient data were obtained at baseline and during follow-up. All patients underwent coronary angiography prior to TAVR and percutaneous coronary intervention (PCI) was typically performed more than 1 week before TAVR to minimise the potential influence of revascularisation on hs-TnT levels. Pre-procedural hs-TnT levels were typically assessed 1 day before TAVR, and were measured again after 1 year, during a routine follow-up visit.

Cardiovascular biomarkers (hs-TnT and N-terminal proB-type natriuretic peptide [NT-proBNP]) were measured using a system obtained from Roche Diagnostics ("Elecsys ${ }^{\circledR}$ Troponin T high sensitive" [10] and "Roche NT-proBNP" [11]) based on the cobas e801 test module (all Roche Diagnostics, Mannheim, Germany). Patient outcomes were analysed following the Valve Academic Research Consortium-2 (VARC-2) system. Follow-up after discharge usually included an in-person visit at our cardiology outpatient clinic 1-3 months after TAVR, as well as an annual followup by either contacting the patients or their general practitioner and cardiologist.

\section{Statistical analyses}

Results are summarised using standard statistical evaluations. Continuous data were expressed as median and interquartile range (IQR), categorical data as counts (percentages). Data were analysed with the Mann-Whitney $U$ test and $X^{2}$ test. In case of few observations (frequency less than 10 for an individual cell), Fisher's exact test was used. Survival data were visualised by Kaplan-Meier curves and compared using log-rank tests.

The cut-off hs-TnT level at 1-year for stratifying risk was determined using receiver operating characteristic (ROC) curve analysis. All pre-procedural variables significantly associated with survival were included in a Cox regression model. Backward selection was based on the likelihood ratio criteria. For each covariate, the proportional hazards assumption was approved by testing for interactions between Schoenfeld residuals and the log-transformed time using the function "cox.zph()" of the "R [survival] package". Results were presented as adjusted hazard ratios (HR) with 95\% confidence intervals (CI).

Statistical analyses were performed using the statistical software GraphPad Prism8, and RStudio, version 1.3.1093.

\section{Results}

Among the 349 patients included in the study, 292 had an hs-TnT level $<39.4 \mathrm{pg} / \mathrm{mL}$ and 57 had an hs-TnT level of $\geq 39.4 \mathrm{pg} / \mathrm{mL}$ at one year.

The median baseline hs-TnT level was $51.2 \mathrm{pg} / \mathrm{mL}$ in the high hs-TnT group compared with $18.3 \mathrm{pg} / \mathrm{mL}$ in the low hs-TnT group $(p<0.001)$. The high hs-TnT group contained a higher proportion of men compared with the low hs-TnT group (57.9\% vs. $41.4 \%, p=0.028)$, and had a higher prevalence of a severely decreased estimated glomerular filtration rate $($ eGFR $)<30 \mathrm{~mL} / \mathrm{min} / 1.73 \mathrm{~m}^{2}$ $(31.6 \%$ vs. $4.5 \%, p<0.001)$ and peripheral artery disease (26.3\% vs. $14.0 \%, p=0.029)$. Increased hs-TnT levels were associated with hallmarks of heart failure with preserved ejection fraction (HFpEF) with a higher median left ventricular (LV) mass (253.1 vs. $216.8 \mathrm{~g}, p=0.005$ ), a higher prevalence of severe diastolic dysfunction $(26.3 \%$ vs. $10.6 \%, p=0.004)$ and a higher median NT-proBNP level (1978 vs. $739.5 \mathrm{pg} / \mathrm{mL}, p<0.001)$. The rate of an LV ejection fraction $<35 \%$ was higher $(12.3 \%$ vs. $4.1 \%$, $p=0.022$ ) compared with the low hs-TnT group (Table 1).

ROC analysis determined that an hs-TnT level of $39.4 \mathrm{pg} / \mathrm{mL}$ was the most appropriate cutoff level for stratifying risk (Fig. 1, Table 2). Of the 349 patients with available 1 year hs-TnT levels, overall mortality rate after 1 year (i.e. within the second year after TAVR) was 5.4\% $(12.3 \%$ vs. $4.1 \%, p=0.010)$. The rate of all-cause mortality during the period from 1 to 5 years after TAVR (median follow-up 49.4 months) was significantly higher among those patients who had an elevated hs-TnT level $(\geq 39.4 \mathrm{pg} / \mathrm{mL})$ at 1 -year post-TAVR compared with those who had a lower 1-year hs-TnT level ( $p=0.010$; Fig. 2).

Factors that were significantly associated with longterm mortality according to the log-rank test included hsTnT level $\geq 39.4 \mathrm{pg} / \mathrm{mL}$, NT-proBNP level $>300 \mathrm{pg} / \mathrm{mL}$, eGFR $<60 \mathrm{~mL} / \mathrm{min}$, male sex, and chronic obstructive pulmonary disease (COPD) (Table 3 ). These five factors were also associated with long-term mortality in univariate Cox regression analysis (Table 4).

Using multivariate analysis, 1 -year hs-TnT $\geq 39.4 \mathrm{pg} / \mathrm{mL}$, NT-proBNP level $>300 \mathrm{pg} / \mathrm{mL}$ ), male sex, eGFR $<60$ $\mathrm{mL} / \mathrm{min} / 1.73 \mathrm{~m}^{2}$ and COPD were confirmed as independent risk factors for long-term mortality after TAVR (Table 4). Notably, an hs-TnT level of $\geq 39.4 \mathrm{pg} / \mathrm{mL}$ at 1 -year post-TAVR was associated with a 2.9 -fold increased risk of long-term mortality (HR 2.93, 95\% CI 1.91-4.49, $p<0.001$ ) (Model 1). If we replaced the hs-TnT cut-off by $\geq 52.0 \mathrm{pg} / \mathrm{mL}$, the risk increased was largely preserved (HR 2.82, 95\% CI 1.64-4.84, $p<0.001$ ) (Model 2). 
Table 1 Characteristics of patients 1 year after TAVR (baseline for this analysis)

\begin{tabular}{|c|c|c|c|c|}
\hline & $\begin{array}{l}\text { Total } \\
(n=349)\end{array}$ & $\begin{array}{l}\text { hs-TnT } \geq 39.4 \mathrm{pg} / \mathrm{mL} \\
(n=57)\end{array}$ & $\begin{array}{l}\text { hs-TnT }<39.4 \mathrm{pg} / \mathrm{mL} \\
(n=292)\end{array}$ & $p$ value \\
\hline Age [years] & $82.0(78.3-86.1)$ & $82.1(76.7-86.7)$ & $82.0(78.4-86.0)$ & 0.904 \\
\hline Female, $n[\%]$ & $195(55.9)$ & $24(42.1)$ & $171(58.6)$ & 0.028 \\
\hline BMI $\left[\mathrm{kg} / \mathrm{m}^{2}\right]$ & $26.7(23.9-30.1)$ & $27.2(23.8-30.5)$ & $26.6(23.9-30.1)$ & 0.863 \\
\hline $\mathrm{CAD}, n[\%]$ & $246(70.5)$ & $36(63.2)$ & $210(71.9)$ & 0.205 \\
\hline COPD, $n[\%]$ & $41(11.7)$ & $10(17.5)$ & $31(10.6)$ & 0.174 \\
\hline $\mathrm{CVD}, n[\%]$ & $80(22.9)$ & $16(28.1)$ & $64(21.9)$ & 0.306 \\
\hline Diabetes mellitus, $n$ [\%] & $109(31.2)$ & $22(38.6)$ & $87(29.8)$ & 0.212 \\
\hline Dyslipidemia, $n$ [\%] & $187(53.6)$ & $26(45.6)$ & $161(55.1)$ & 0.195 \\
\hline History of AF, $n$ [\%] & $124(35.5)$ & $26(45.6)$ & $98(33.6)$ & 0.096 \\
\hline Hypertension, $n$ [\%] & $313(89.7)$ & $50(87.7)$ & $263(90.1)$ & 0.634 \\
\hline $\mathrm{PAD}, n[\%]$ & $56(16.0)$ & $15(26.3)$ & $41(14.0)$ & 0.029 \\
\hline $\mathrm{PAH}, n[\%]$ & $39(11.2)$ & $9(15.8)$ & $30(10.3)$ & 0.250 \\
\hline \multicolumn{5}{|l|}{ LVEF } \\
\hline$<35 \%, n[\%]$ & $19(5.4)$ & $7(12.3)$ & $12(4.1)$ & 0.022 \\
\hline $35-45 \%, n[\%]$ & $38(10.9)$ & $7(12.3)$ & $31(10.6)$ & 0.648 \\
\hline $45-55 \%, n[\%]$ & $54(15.5)$ & $10(17.5)$ & $44(15.1)$ & 0.689 \\
\hline$>55 \%, n[\%]$ & $238(68.2)$ & $33(57.9)$ & $205(70.2)$ & 0.087 \\
\hline RV dysfunction, $n[\%]$ & $60(17.2)$ & $14(24.6)$ & $46(15.8)$ & 0.124 \\
\hline \multicolumn{5}{|l|}{ eGFR $\left[\mathrm{mL} / \mathrm{min} / 1.73 \mathrm{~m}^{2}\right]$} \\
\hline$<30, n[\%]$ & $31(8.9)$ & 18 (31.6) & $13(4.5)$ & $<0.001$ \\
\hline $30-45, n[\%]$ & $105(30.1)$ & $19(33.3)$ & $86(29.5)$ & 0.636 \\
\hline $45-60, n[\%]$ & $104(29.8)$ & $11(19.3)$ & $93(31.8)$ & 0.060 \\
\hline$>60, n[\%]$ & $109(31.2)$ & $9(15.8)$ & $100(34.2)$ & 0.005 \\
\hline Prev. cardiac surgery, $n[\%]$ & $74(21.2)$ & $11(19.3)$ & $63(21.6)$ & 0.860 \\
\hline hs-TnT [pg/mL] & $20.8(13.9-32.3)$ & $51.2(44.3-69.7)$ & $18.3(12.7-25.7)$ & $<0.001$ \\
\hline NT-proBNP [pg/mL] & $835.5(378.0-1773.0)$ & $1978(749.2-4609.0)$ & $739.5(356.8-1434.0)$ & $<0.001$ \\
\hline AVA $\left[\mathrm{cm}^{2}\right]$ & $1.7(1.4-2.0)$ & $1.7(1.4-2.0)$ & $1.6(1.4-1.9)$ & 0.487 \\
\hline MPG [mmHg] & $11.0(8.0-15.0)$ & $9.5(8.0-14.3)$ & $11.0(8.0-15.0)$ & 0.445 \\
\hline LV mass $[\mathrm{g}]$ & $224.2(184.7-282.0)$ & $253.1(205.8-301.8)$ & $216.8(180.9-280.1)$ & 0.005 \\
\hline Severe diastolic dysfunction ${ }^{1}$ & $46(13.2)$ & $15(26.3)$ & $31(10.6)$ & 0.004 \\
\hline Severe LA enlargement ${ }^{1,2}$ & $59(16.9)$ & $14(24.6)$ & $45(15.4)$ & 0.092 \\
\hline $\mathrm{AR} \geq$ moderate & $3(0.9)$ & $1(1.8)$ & $2(0.7)$ & 0.415 \\
\hline MR III-IV & $61(17.5)$ & $9(15.8)$ & $52(17.8)$ & 0.849 \\
\hline TR III-IV & $44(12.6)$ & $5(8.8)$ & $39(13.4)$ & 0.512 \\
\hline Transfemoral TAVR & $240(68.8)$ & $37(64.9)$ & $203(69.5)$ & 0.533 \\
\hline Balloon-expandable valve & $276(79.1)$ & $48(84.2)$ & $228(78.1)$ & 0.298 \\
\hline Mortality rate after 1 year & $19(5.4)$ & $7(12.3)$ & $12(4.1)$ & $0.010^{3}$ \\
\hline
\end{tabular}

Values are presented as counts (percentages) or median (IQR)

$A F$ atrial fibrillation, $A R$ aortic regurgitation, $A V A$ aortic valve area, $B M I$ body mass index, $C A D$ coronary artery disease, $C O P D$ chronic obstructive pulmonary disease, $C V D$ cerebrovascular disease, $e G F R$ estimated glomerular filtration rate, $E S$ EuroScore, $h s-T n T$ high-sensitivity troponin $\mathrm{T}, L V$ left ventricular, $L V E F$ left ventricular ejection fraction, $M P G$ mean pressure gradient, $M R$ mitral regurgitation, $N T$-proBNP $\mathrm{N}$-terminal pro-B-type natriuretic peptide, $P A D$ peripheral artery disease, $P A H$ pulmonary arterial hypertension, $R V$ right ventricle, $R V S P$ right ventricular systolic pressure, $T A V R$ transcatheter aortic valve replacement, $T R$ tricuspid regurgitation

${ }^{1}$ Measurements were not available in two patients due to limited acoustic windows or missing data

${ }^{2} \mathrm{LA}$ volume index $\geq 40 \mathrm{~mL} / \mathrm{m}^{2}$ or LA diameter index $\geq 3.0 \mathrm{~cm} / \mathrm{m}^{2}$

${ }^{3} p$ value was calculated using the log-rank test 


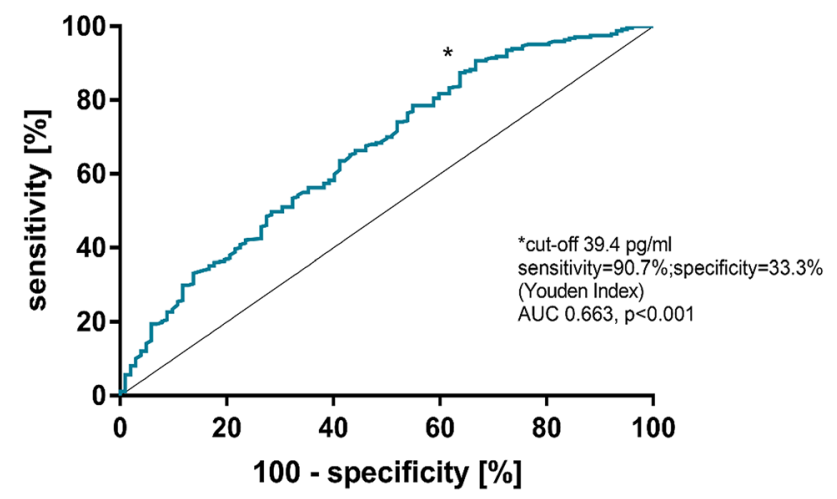

Fig. 1 Receiver operating characteristic curve analysis of high-sensitivity troponin T cut-off value. AUC area under the curve

\section{Discussion}

The main finding of our study is that elevated hs-TnT levels at 1-year after successful TAVR are still independently associated with worse long-term survival.

Previous studies have established that elevated preprocedural hs-TnT levels in patients with AS are prognostic for survival after TAVR $[5,7,8,12]$. A meta-analysis confirmed that high pre-procedural TnT levels were associated with significant increases in 30-day $(p=0.002)$ and mid-term mortality $(p<0.00001)$ [13]. Studies evaluating the potential prognostic role of hs-TnT measured shortly after TAVR have produced conflicting results $[5,6,8,14$, 15], although one meta-analysis found that high post-procedural TnT levels were also associated with significant increases in 30-day $(p<0.0001)$ and mid-term $(p<0.0003)$ mortality [13].

With respect to longer follow-up, one study reported that elevation of troponin I (TnI) levels at 3 months postTAVR was independently associated with an increased risk of 1-year mortality after TAVR (HR 4.4, 95\% CI 2.0-9.7, $p<0.001$ ) [6]. However, until now, it has not been established whether troponin levels measured later during postTAVR follow-up can still provide prognostic information about long-term outcomes. To our knowledge, our study is the first to address this question and it has shown that an elevated hs-TnT level at 1 -year (defined as $\geq 39.4 \mathrm{pg} / \mathrm{mL}$ )

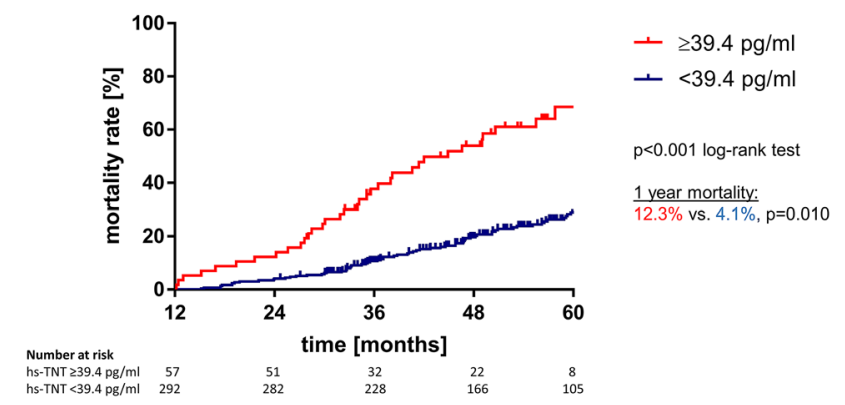

Fig. 2 Persistently elevated hs-TnT concentrations at 1 year after TAVR are associated with a higher mortality rates over the long-term. $h s-T n T$ high-sensitivity troponin $\mathrm{T}, T A V R$ transcatheter aortic valve replacement

Table 3 Factors assessed at 1-year post-TAVR that were associated with long-term mortality (log-rank test)

\begin{tabular}{lr}
\hline & $p$ value \\
\hline hs-TnT $\geq 39.4 \mathrm{pg} / \mathrm{mL}$ & $<0.001$ \\
hs-TnT $\geq 52.0 \mathrm{pg} / \mathrm{mL}$ & $<0.001$ \\
Male gender & 0.038 \\
COPD & 0.022 \\
eGFR $<60 \mathrm{~mL} / \mathrm{min}$ & 0.002 \\
NT-proBNP $>300 \mathrm{pg} / \mathrm{mL}$ & 0.010 \\
\hline
\end{tabular}

COPD chronic obstructive pulmonary disease, $e G F R$ estimated glomerular filtration rate, $h s-T n T$ high-sensitivity troponin T, NTproBNP N-terminal pro-B-type natriuretic peptide

after successful TAVR was independently associated with an increased risk of mortality during the subsequent 4 years, with a HR 2.93 .

The hs-TnT cut-off level used for risk stratification $(\geq 39.4 \mathrm{pg} / \mathrm{mL}$ ) was calculated using ROC analysis. In our cohort, it reached a sensitivity of $>90 \%$ and a sensitivity of $>33 \%$. Choosing a higher hs-TnT cut-off $[16,17]$ would have increased sensitivity, yet decreased specificity. In addition, using a cut-off of $52 \mathrm{pg} / \mathrm{mL}$ or $100 \mathrm{pg} / \mathrm{mL}$ would have significantly limited our sample size. Therefore, the cut-off of $\geq 39.4 \mathrm{pg} / \mathrm{mL}$ seemed to be reasonable in our cohort. Nevertheless, a cut-off of $\geq 52 \mathrm{pg} / \mathrm{mL}$ was also independently associated with further mortality after TAVR. Thus, our analysis indicates that the concept of hs-TnT as a prognostic biomarker after TAVR also holds true when using
Table 2 Comparison of different cut-offs for hs-TnT $[16,17]$

\begin{tabular}{llclc}
\hline hs-TnT cut-off & $\begin{array}{l}\text { Sensitivity [\%] } \\
(95 \% \text { CI })\end{array}$ & $\begin{array}{l}\text { Specificity [\%] } \\
(95 \% \text { CI })\end{array}$ & Likelihood ratio & Youden-Index \\
\hline$\geq 39.4 \mathrm{pg} / \mathrm{mL}(n=57)$ & $90.7(86.4-94.0)$ & $33.3(24.3-43.4)$ & 1.36 & 124.0 \\
$\geq 52.0 \mathrm{pg} / \mathrm{mL}(n=27)$ & $96.0(92.7-98.0)$ & $16.7(10.0-25.3)$ & 1.15 & 112.6 \\
$>100 \mathrm{pg} / \mathrm{mL}(n=6)$ & $99.6(97.8-99.9)$ & $3.9(1.1-9.7)$ & 1.03 & 103.5 \\
\hline
\end{tabular}

$h s$-TnT high-sensitivity troponin T, $C I$ confidence interval 
Table 4 Cox regression analysis of factors assessed at 1-year post-TAVR that were associated with long-term mortality

\begin{tabular}{|c|c|c|c|c|}
\hline \multirow[t]{2}{*}{ Variable } & \multicolumn{2}{|l|}{ Univariate analysis } & \multicolumn{2}{|c|}{ Multivariate analysis } \\
\hline & HR $(95 \%$ CI $)$ & $p$ value & $\mathrm{HR}(95 \% \mathrm{CI})$ & $p$ value \\
\hline \multicolumn{5}{|c|}{ Model 1 (hs-TnT cut-off $\geq 39.4 \mathrm{pg} / \mathrm{mL}$ ) } \\
\hline hs-TnT $\geq 39.4 \mathrm{pg} / \mathrm{mL}$ & $3.60(2.38-5.45)$ & $<0.001$ & $2.93(1.91-4.49)$ & $<0.001$ \\
\hline Male gender & $1.50(1.02-2.22)$ & 0.040 & $1.64(1.10-2.44)$ & 0.014 \\
\hline COPD & $1.80(1.08-3.0)$ & 0.024 & $1.91(1.14-3.20)$ & 0.015 \\
\hline $\mathrm{eGFR}<60 \mathrm{~mL} / \mathrm{min} / 1.73 \mathrm{~m}^{2}$ & $2.11(1.30-3.41)$ & 0.002 & $1.80(1.09-2.96)$ & 0.021 \\
\hline NT-proBNP $>300 \mathrm{pg} / \mathrm{mL}$ & $2.30(1.20-4.42)$ & 0.012 & $2.16(1.12-4.18)$ & 0.022 \\
\hline \multicolumn{5}{|c|}{ Model 2 (hs-TnT cut-off $\geq 52.0 \mathrm{pg} / \mathrm{mL}$ ) } \\
\hline hs-TnT $\geq 52.0 \mathrm{pg} / \mathrm{mL}$ & $3.73(2.20-6.32)$ & $<0.001$ & $2.82(1.64-4.84)$ & $<0.001$ \\
\hline Male gender & $1.50(1.02-2.22)$ & 0.031 & $1.63(1.10-2.42)$ & 0.015 \\
\hline COPD & $1.80(1.08-3.0)$ & 0.031 & $1.91(1.14-3.22)$ & 0.014 \\
\hline $\mathrm{eGFR}<60 \mathrm{~mL} / \mathrm{min} / 1.73 \mathrm{~m}^{2}$ & $2.11(1.30-3.41)$ & 0.023 & $1.95(1.19-3.19)$ & 0.008 \\
\hline NT-proBNP > $300 \mathrm{pg} / \mathrm{mL}$ & $2.30(1.20-4.42)$ & $<0.001$ & $2.20(1.14-4.26)$ & 0.019 \\
\hline
\end{tabular}

Results are presented as adjusted hazard ratios (HR) with $95 \%$ confidence intervals (CI). Model 1: Global Schoenfeld test: $X^{2}=3.315, p=0.652$. Model 2: Global Schoenfeld test: $X^{2}=3.320, p=0.669$

$C O P D$ chronic obstructive pulmonary disease, $e G F R$ estimated glomerular filtration rate, $h s-T n T$ high-sensitivity troponin $\mathrm{T}, N T$-proBNP $\mathrm{N}$-terminal pro-B-type natriuretic peptide a population-independent hs-TnT cut-off. The results of the study suggest that monitoring hs-TnT levels during post-TAVR follow-up could help identify those patients at increased risk of mortality after TAVR, which could facilitate individualised management strategies.

Troponin $\mathrm{T}$ is a marker of cardiomyocyte damage. Stenosis of the aortic valve causes an increase in LV afterload, leading to LV hypertrophy, which can result in chronic myocardial injury and fibrosis, and thus hallmarks of HFpEF [18]. In fact, increased hs-TnT levels were associated with diastolic dysfunction, LV mass and NT-proBNP. In patients with AS, hs-TnT and hs-TnI levels have been shown to correlate with markers of cardiac remodelling, such as LV mass (reflecting LV hypertrophy), [18-21]. As would be expected, in our study the group of patients with an elevated hs-TnT at baseline had a higher median LV mass than those with a lower hs-TnT level.

NT-proBNP is another marker of myocardial damage. Some studies have found that elevated pre-procedural or early post-procedural levels of NT-proBNP are predictive of mortality in AS patients who undergo TAVR [22-25]. Other studies indicated that NT-proBNP levels that do not decrease after TAVR are predictive of mortality [26, 27]. During longer follow-up, an elevated NT-proBNP level at 30 days post-TAVR, and an increase in NT-proBNP level from baseline to 30 days, have been identified as independent predictors of 1-year mortality [28-30]. However, one of the studies suggested that post-procedural NTproBNP levels need to be interpreted in the context of the TAVR access route used, with the highest prognostic relevance seen for transfemoral TAVR patients with aortic regurgitation and reduced LV function [25]. Our study found that an NT-proBNP level $>300 \mathrm{pg} / \mathrm{mL}$ at 1 -year post-TAVR was an independent predictor of longterm mortality $(p<0.010)$ [31, 32].

In addition to 1-year hs-TnT and NT-proBNP levels, we also identified COPD and male sex as independent risk factors for long-term mortality after TAVR. Our findings are consistent with previous studies that have shown that COPD is associated with an increased risk of short- and long-term mortality after TAVR [33-36]. Previous studies on gender differences in outcomes after TAVR have produced conflicting results, but meta-analyses suggest that female gender may be independently associated with better mid-term survival (0.5-1 years) [37-39]. Our findings concerning gender and long-term mortality are consistent with this.

The study has several potential limitations. It was a retrospective, single-centre study with a focus on survival. There may have been a degree of selection bias with respect to the patient population, as only those patients who were healthy enough to do so would have returned for a 1-year follow-up visit. The echocardiography data used in the study were obtained by different physicians and some data were only partially available from the patient files. Our analysis did not specifically address patients who crossed over (i.e., patients who had low hs-TnT values pre-procedure, but high values afterwards, or vice versa), and it may be worthwhile considering such an analysis in the future. 


\section{Conclusion}

An increased hs-TnT level at 1-year after TAVR correlated highly significantly with poor long-term survival. This suggests a potential role for hs-TnT in risk stratification during long-term follow-up of patients after TAVR.

Author contributions Study conception and design: HS, ML, VW, DF. Acquisition of data: HS, ML, LD, VW, JF, CH. Analysis and interpretation of data: HS, ML, LD, VW, SFW, JF, CH, AYR, GL, PB, NF, DF. Drafting of manuscript: HS, PB, DF. Critical revision: ML, LD, VW, SFW, JF, CH, AYR, GL, NF.

Funding Open Access funding enabled and organized by Projekt DEAL.

\section{Compliance with ethical standards}

Conflict of interest Hatim Seoudy, Moritz Lambers, Linnea Dudlik, Vincent Winkler, Sandra-Freitag-Wolf, Johanne Frank, Christian Kuhn, and Ashraf Yusuf Rangrez declare no conflict of interest. Peter Bramlage received research funding and honoraria for his advisory role from Edwards Lifesciences and Abbott. Georg Lutter is a consultant for Edwards Lifesciences, Medtronic, BostonScientific, and Abbott. Norbert Frey declares no conflict of interest for this study, yet has received speaker honoraria from AstraZeneca, Bayer Healthcare, Boehringer Ingelheim, Edwards, and Novartis. Derk Frank is consultant for Edwards Lifesciences and Medtronic and has received research funding from Edwards Lifesciences.

Ethics approval The study was performed in accordance with the ethical standards laid down in the 1975 Declaration of Helsinki and was approved by the Ethics Committee at the University of Kiel, Germany. Informed consent was obtained from all participants.

Open Access This article is licensed under a Creative Commons Attribution 4.0 International License, which permits use, sharing, adaptation, distribution and reproduction in any medium or format, as long as you give appropriate credit to the original author(s) and the source, provide a link to the Creative Commons licence, and indicate if changes were made. The images or other third party material in this article are included in the article's Creative Commons licence, unless indicated otherwise in a credit line to the material. If material is not included in the article's Creative Commons licence and your intended use is not permitted by statutory regulation or exceeds the permitted use, you will need to obtain permission directly from the copyright holder. To view a copy of this licence, visit http://creativecommons.org/licenses/by/4.0/.

\section{References}

1. Iung B, Baron $\mathrm{G}$, Butchart EG et al (2003) A prospective survey of patients with valvular heart disease in Europe: the Euro heart survey on valvular heart disease. Eur Heart J 24:1231-1243

2. Baumgartner H, Falk V, Bax JJ et al (2017) 2017 ESC/EACTS guidelines for the management of valvular heart disease. Eur Heart J 38:2739-2791. https://doi.org/10.1093/eurheartj/ehx391

3. Mack MJ, Leon MB, Thourani VH et al (2019) Transcatheter aortic-valve replacement with a balloon-expandable valve in low-risk patients. N Engl J Med 380:1695-1705. https://doi. org/10.1056/NEJMoa1814052

4. Redfors B, Furer A, Lindman BR et al (2017) Biomarkers in aortic stenosis: a systematic review. Struct Heart 1:18-30. https ://doi.org/10.1080/24748706.2017.1329959

5. Kohler WM, Freitag-Wolf S, Lambers M et al (2016) Preprocedural but not periprocedural high-sensitive Troponin $\mathrm{T}$ levels predict outcome in patients undergoing transcatheter aortic valve implantation. Cardiovasc Ther 34:385-396. https://doi. org/10.1111/1755-5922.12208

6. Sinning JM, Hammerstingl C, Schueler R et al (2016) The prognostic value of acute and chronic troponin elevation after transcatheter aortic valve implantation. EuroIntervention 11:15221529. https://doi.org/10.4244/EIJY15M02_02

7. Frank D, Stark S, Lutz M et al (2013) Preprocedural highsensitive troponin predicts survival after transcatheter aortic valve implantation (TAVI). Int J Cardiol 169:e38-39. https:// doi.org/10.1016/j.ijcard.2013.08.108

8. Chorianopoulos E, Krumsdorf U, Geis N et al (2014) Preserved prognostic value of preinterventional troponin $\mathrm{T}$ levels despite successful TAVI in patients with severe aortic stenosis. Clin Res Cardiol 103:65-72. https://doi.org/10.1007/s00392-013-0624-8

9. Januzzi JL Jr, Filippatos G, Nieminen M, Gheorghiade M (2012) Troponin elevation in patients with heart failure: on behalf of the third universal definition of myocardial infarction global task force: heart failure section. Eur Heart J 33:2265-2271. https://doi. org/10.1093/eurheartj/ehs191

10. Koerbin G, Tate JR, Hickman PE (2010) Analytical characteristics of the Roche highly sensitive troponin T assay and its application to a cardio-healthy population. Ann Clin Biochem 47:524-528. https://doi.org/10.1258/acb.2010.010033

11. Di Serio F, Ruggieri V, Varraso L, De Sario R, Mastrorilli A, Pansini N (2005) Analytical evaluation of the Dade Behring Dimension RxL automated N-terminal proBNP (NT-proBNP) method and comparison with the Roche Elecsys 2010. Clin Chem Lab Med 43:1263-1273. https://doi.org/10.1515/CCLM.2005.217

12. Kofler M, Reinstadler SJ, Stastny L et al (2017) Prognostic implications of pre-procedural high-sensitivity cardiac troponin $\mathrm{T}$ in patients undergoing transcatheter aortic valve replacement. JACC Cardiovasc Interv 10:2345-2346. https://doi.org/10.1016/j. jcin.2017.09.020

13. Takagi H, Hari Y, Nakashima K, Kuno T, Ando T, All-Literature Investigation of Cardiovascular Evidence G (2020) Meta-analysis of impact of troponins on mortality after transcatheter aortic valve implantation. J Cardiovasc Surg 61:98-106. https://doi. org/10.23736/S0021-9509.19.11023-3

14. Koifman E, Garcia-Garcia HM, Alraies MC et al (2017) Correlates and significance of elevation of cardiac biomarkers elevation following transcatheter aortic valve implantation. Am J Cardiol 120:850-856. https://doi.org/10.1016/j.amjcard.2017.05.059

15. Koskinas KC, Stortecky S, Franzone A et al (2016) Post-procedural troponin elevation and clinical outcomes following transcatheter aortic valve implantation. J Am Heart Assoc. https:// doi.org/10.1161/JAHA.115.002430

16. Collet JP, Thiele H, Barbato E et al (2020) 2020 ESC Guidelines for the management of acute coronary syndromes in patients presenting without persistent ST-segment elevation. Eur Heart J. https://doi.org/10.1093/eurheartj/ehaa575

17. Klein G, Kampmann M, Baum H et al (1998) Clinical performance of the new cardiac markers troponin $\mathrm{T}$ and CK-MB on the Elecsys 2010. A multicentre evaluation. Wien Klin Wochenschr 110(Suppl 3):40-51

18. McCarthy CP, Donnellan E, Phelan D, Griffin BP, EnriquezSarano M, McEvoy JW (2017) High sensitivity troponin and valvular heart disease. Trends Cardiovasc Med 27:326-333. https:// doi.org/10.1016/j.tcm.2017.01.004 
19. Rosjo H, Andreassen J, Edvardsen T, Omland T (2011) Prognostic usefulness of circulating high-sensitivity troponin $\mathrm{T}$ in aortic stenosis and relation to echocardiographic indexes of cardiac function and anatomy. Am J Cardiol 108:88-91. https://doi. org/10.1016/j.amjcard.2011.02.346

20. Solberg OG, Ueland T, Wergeland R et al (2012) High-sensitive troponin $\mathrm{T}$ and $\mathrm{N}$-terminal-brain-natriuretic-peptide predict outcome in symptomatic aortic stenosis. Scand Cardiovasc J 46:278285. https://doi.org/10.3109/14017431.2012.687836

21. Chin CW, Shah AS, McAllister DA et al (2014) High-sensitivity troponin I concentrations are a marker of an advanced hypertrophic response and adverse outcomes in patients with aortic stenosis. Eur Heart J 35:2312-2321. https://doi.org/10.1093/eurhe artj/ehu 189

22. Koskinas KC, O’Sullivan CJ, Heg D et al (2015) Effect of B-type natriuretic peptides on long-term outcomes after transcatheter aortic valve implantation. Am J Cardiol 116:1560-1565. https:// doi.org/10.1016/j.amjcard.2015.08.016

23. Abramowitz Y, Chakravarty T, Jilaihawi $\mathrm{H}$ et al (2015) Impact of preprocedural B-type natriuretic peptide levels on the outcomes after transcatheter aortic valve implantation. Am J Cardiol 116:1904-1909. https://doi.org/10.1016/j.amjcard.2015.09.031

24. Mizutani K, Hara M, Iwata S et al (2017) Elevation of B-type natriuretic peptide at discharge is associated with 2-year mortality after transcatheter aortic valve replacement in patients with severe aortic stenosis: insights from a multicenter prospective OCEAN-TAVI (Optimized Transcatheter Valvular InterventionTranscatheter Aortic Valve Implantation) Registry. J Am Heart Assoc. https://doi.org/10.1161/jaha.117.006112

25. Liebetrau C, Gaede L, Kim WK et al (2018) Early changes in $\mathrm{N}$-terminal pro-B-type natriuretic peptide levels after transcatheter aortic valve replacement and its impact on long-term mortality. Int J Cardiol 265:40-46. https://doi.org/10.1016/j.ijcard.2018.02.037

26. Kaneko H, Hoelschermann F, Tambor G, Okamoto M, Neuss M, Butter C (2019) Impact of N-terminal pro-B-type natriuretic peptide response on long-term prognosis after transcatheter aortic valve implantation for severe aortic stenosis and heart failure. Heart Vessels 34:777-783. https://doi.org/10.1007/s0038 0-018-1297-z

27. Onoda H, Ueno H, Ueno Y, Kuwahara H, Sobajima M, Kinugawa K (2019) The impact of changes in B-type natriuretic peptide levels on prognosis after transcatheter aortic valve implantation. Cardiovasc Interv Ther. https://doi.org/10.1007/s12928-019-00621-w

28. Gotzmann M, Czauderna A, Aweimer A et al (2014) B-type natriuretic peptide is a strong independent predictor of long-term outcome after transcatheter aortic valve implantation. J Heart Valve Dis 23:537-544

29. O'Neill BP, Guerrero M, Thourani VH et al (2015) Prognostic value of serial B-type natriuretic peptide measurement in transcatheter aortic valve replacement (from the PARTNER Trial). Am J Cardiol 115:1265-1272. https://doi.org/10.1016/j. amjcard.2015.01.561

30. Vale NC, Campante Teles R, Madeira S et al (2018) Post-procedural N-terminal pro-brain natriuretic peptide predicts one-year mortality after transcatheter aortic valve implantation. Rev Port Cardiol 37:67-73. https://doi.org/10.1016/j.repc.2017.06.016

31. Roberts E, Ludman AJ, Dworzynski K et al (2015) The diagnostic accuracy of the natriuretic peptides in heart failure: systematic review and diagnostic meta-analysis in the acute care setting. BMJ 350:h910. https://doi.org/10.1136/bmj.h910

32. Januzzi JL Jr, Camargo CA, Anwaruddin S et al (2005) The $\mathrm{N}$-terminal Pro-BNP investigation of dyspnea in the emergency department (PRIDE) study. Am J Cardiol 95:948-954. https://doi. org/10.1016/j.amjcard.2004.12.032

33. Mok M, Nombela-Franco L, Dumont E et al (2013) Chronic obstructive pulmonary disease in patients undergoing transcatheter aortic valve implantation: insights on clinical outcomes, prognostic markers, and functional status changes. JACC Cardiovasc Interv 6:1072-1084. https://doi.org/10.1016/j.jcin.2013.06.008

34. van Mourik MS, Velu JF, Lanting VR et al (2020) Preoperative frailty parameters as predictors for outcomes after transcatheter aortic valve implantation: a systematic review and meta-analysis. Neth Heart J 28:280-292. https://doi.org/10.1007/s12471-02001379-0

35. Rodés-Cabau J, Webb JG, Cheung A et al (2012) Long-term outcomes after transcatheter aortic valve implantation: insights on prognostic factors and valve durability from the Canadian multicenter experience. J Am Coll Cardiol 60:1864-1875. https://doi. org/10.1016/j.jacc.2012.08.960

36. Liao YB, He ZX, Zhao ZG et al (2016) The relationship between chronic obstructive pulmonary disease and transcatheter aortic valve implantation-a systematic review and meta-analysis. Catheter Cardiovasc Interv 87(Suppl 1):570-578. https://doi. org/10.1002/ccd.26443

37. Takagi H, Umemoto $\mathrm{T}$ (2017) Better midterm survival in women after transcatheter aortic valve implantation. J Cardiovasc Surg (Torino) 58:624-632. https://doi.org/10.23736/s0021 $-9509.16 .09382-4$

38. Gaglia MA Jr, Lipinski MJ, Torguson R et al (2016) Comparison in men versus women of co-morbidities, complications, and outcomes after transcatheter aortic valve implantation for severe aortic stenosis. Am J Cardiol 118:1692-1697. https://doi. org/10.1016/j.amjcard.2016.08.049

39. Conrotto F, D'Ascenzo F, Presbitero P et al (2015) Effect of gender after transcatheter aortic valve implantation: a meta-analysis. Ann Thorac Surg 99:809-816. https://doi.org/10.1016/j.athoracsur .2014.09.089 